\title{
A Study on Physical Education Teachers' Training Programme on Development of Attitude towards Physical Education
}

\author{
Bhaskar Chakraborty ${ }^{1}$, Somnath Nandy ${ }^{2}$, Samirranjan Adhikari ${ }^{3}$ \\ ${ }^{1,2}$ Research Scholar, Department of Physical Education, University of Kalyani, Kalyani, Nadia, W. B., India, \\ ${ }^{3}$ Assistant Professor in Psychology, Shimurali Sachinandan College of Education, Shimurali, Nadia, W.B., India.
}

\begin{abstract}
Perspectives: Physical education takes a crucial role in education. Truly to educate our future generation and to help them to lead healthy and prosperous life, side by side with the general education physical education in its augmented total quality is to be introduced from early school level. Now, to maintain total quality of physical education we have to take scientific footing to discern the attitude of the students as well as the teachers of Secondary and Higher Secondary schools towards physical education as a preliminary step. This one was a longitudinal study carried out through quasi-experimental research design. A sample of 128 B.P.Ed students was chosen from different teacher education institutions of West Bengal by stratified random sampling technique The Attitudes toward Physical Education Scale was administered on the sample in three different phases - at the beginning, in the middle and at the end of the session. From the Paired Samples " $t$ " test it was observed that there was statistically significant increase in the mean of the attitude scores from the $1^{\text {st }}$ phase $(M=98.41)$ to the $2^{\text {nd }}$ phase of testing $(M=102.01)$ and again to the $3^{\text {rd }}$ phase of testing $(M=105.24)$.
\end{abstract}

Key Words: Anxiety, State and Trait Anxiety, Quasi-Experimental Research Design

\section{Attitude towards the Physical Education}

Students' attitudes toward physical education have been under investigation since the 1930's. Traditionally, the purpose of such inquiry has been to identify factors that contribute to positive and negative feelings toward physical education. It is believed that having such information would improve the quality of physical education by allowing teachers to consider student insights when making curricular or programme decisions.

In recent years, there has been an increase in the body of knowledge in physical education in terms of student attitudes. The increase in interest may also be attributed to the influence of attitudes toward future participation in physical activities outside school (Carlson, 1994; Ennis, 1996; Portman, 1995), to student achievement in physical education (Graham, 1995; Lee, 1997; Silverman, 1993; Subramaniam \& Silverman, 2000), and to the availability of knowledge gained about students' attitudes toward physical education for developing curricula (Cothran \& Ennis, 1998).

According to Luke and Cope (1994), programs based on interests and needs have an influence on the efficiency of the teacher in teaching and helping students understand and believe in the importance of physical education and develop positive attitudes. Teacher's behaviour, classroom, family and school administration play a crucial role in the formation of students' attitudes (Aicinena, 1991). According to Fowler (1974), awareness of the primary students on teachers' behaviour enhances positive attitude towards physical education. The findings of Stensaasens suggest that the 7th, 8th and 9th graders developed negative attitude towards teacher-centred learning (Aicinena 1991). It is also important for the students to get into one to one interaction with the teacher to develop positive attitude (Figley, 1985). Hunter's study (1956) suggests that high school grader females are contented with teacher interaction. Therefore, teachers should ensure active student participation in classroom activities (Aicinena, 1991). According to Figley (1985), students adopt negative attitude when the feel that the teacher pays little attention. Physical environment, peer behaviours, evaluation, exercise partner, stages of learning and difficulty level of learning the activities, etc. have an effect on positive attitude development. Crowded classrooms result in negative attitude among students.

Humiliation and hesitation avoids participation. Unnecessary repetition and superficiality have an effect on positive attitude. A study by Machintosh and Albinson (1982) suggests that students who selected physical education adopted positive attitude towards the lessons and school. A study by Haladyna and Thomas (1979), the attitude average of primary school children in physical education, art and music was higher than that in other subjects.

Earl and Stennet (1987) analysed the attitudes of the students towards physical education and health education. Students replied the question why they did not take up physical education and the replies showed that they did not like the activities (64\%), did not like sports (42\%), did not enjoy the lesson (40\%) and did not like the teacher (39\%) (Luke \& Cope, 1994). In a research by Browne (1992) carried out in West Australia, it was emphasized that participation in physical education activities decreased from $44 \%$ to $37 \%$. In a study carried out 
on 103 female students at the age of 12, who did and did not take up physical education, 99\% stated that they liked physical education lesson, $95.2 \%$ found the lesson entertaining and $94.1 \%$ stated they took up this lesson so as to get out of the classroom.95.2\% of the female students who did not take up the physical education lesson stated that other lessons were of more importance for their future careers, $57.3 \%$ stated their programme would not allow, and 39.8\% stated that the exercises they did outside the school were efficient.

\subsection{Physical Education}

Physical education is an important educational process. It aims at the improvement of human performance and enhancement of human development through the medium of physical activities. It is a vital element in a comprehensive well balanced curriculum. It can also be a major contributing factor in the development of an individual in all aspects (i.e. physical, emotional, mental and social) of life.

In teachers education programme in physical education i.e. B.P.Ed. there is an intensive training course in physical education. In B.P.Ed. course both pedagogical and physical activities are included in the curriculum. The impact of this course on the development of some psychological and physical characteristics has been studied earlier by several researchers (Adhikari, 2008; 2010 and 2010a).

\section{Objective of the Study}

We know it very well that the one-year teachers training programme in Physical Education i.e. B. P. Ed. course has tremendous impact on physical and psychological wellbeing of the prospective teachers in Physical Education. However, related literature reveals that there are only a few studies to probe into the effect of B. P. Ed. course on psychosomatic development on scientific footing. The present study is designed to explore the impact of B. P. Ed. Course on the development of Attitude towards Physical Education.

\section{Method}

The present study was longitudinal in nature. It was carried out through quasi-experimental research design. The details regarding sample, tools, procedure of data collection and statistical technique are reported as under:

\section{Participants}

Colleges and University Departments, imparting B.P.Ed. Course in West Bengal were our source of sample. Total sample size of the present study was 128 B.P.Ed students. Stratified Random Sampling Technique was adopted in drawing sample. Only Bengali speaking subjects were taken.

\section{Research Tool : Attitudes toward Physical Education Scale - Demirhan, \& Altay, 2001:}

Demirhan and Altay (2001) develop the "Attitude toward Physical Education Scale" for Turkish students. This is a paper and pencil self-report instrument with a 5-point Likert-type scale with responses ranging from 1 (Strongly Disagree) to 5 (Strongly Agree) summed across 24 items, resulting in a range from 24 to 120. A score of 24 indicates the most negative attitude; a score of 25-48 indicates a negative attitude; 49-72 a neutral attitude; 73-94 a positive attitude; and 95-120 the most positive attitude.

\subsection{Procedure}

"Attitude toward Physical Education Scale" was administered on the subjects in three different phases during an academic session and the responses were scored as per scoring procedure, prescribed in the manual.

The tool was administered in three phases -

In the first phase, the test was administered at the beginning of the B.P.Ed. course (in the $1^{\text {st }}$ week of July); In the second phase the same test was administered in the middle of the course; and In the final phase, the same test was administered at the completion of the course (i.e. before study leave).

\section{Statistical Analysis}

Paired Samples "t" - test was done with the help of SPSS 13.0 software.

\section{Results}

Result of the present investigation is furnished in the following tables.

Table - 1: Paired Samples Statistics

\begin{tabular}{|c|c|c|c|c|}
\hline Pair & Attitude & Mean & N & Std. Deviation \\
\hline \multirow{2}{*}{ Pair $_{1}$} & Attitude $_{1}$ & 98.41 & 128 & 9.12 \\
\cline { 2 - 5 } & Attitude $_{2}$ & 102.01 & 128 & 7.96 \\
\hline \multirow{2}{*}{ Pair $_{2}$} & Attitude $_{2}$ & 102.01 & 128 & 7.96 \\
\cline { 2 - 5 } & Attitude $_{3}$ & 105.24 & 128 & 11.21 \\
\hline
\end{tabular}

From the Tables -1 it is observed that mean of the attitude scores of the B.P.Ed. students increased as the course was advanced towards the completion. The means of the attitude scores in the $1^{\text {st }}$ phase of testing was 

98.41 , in the $2^{\text {nd }}$ phase of testing was 102.01 and in the $3^{\text {rd }}$ phase of testing was 105.24.

Table - 2: Paired Samples Correlations

\begin{tabular}{|c|c|c|c|c|}
\hline Pair & Attitude & $\mathbf{N}$ & Correlation & Sig. \\
\hline Pair $_{1}$ & Attitude $_{1} \&$ Attitude 2 & 128 & 0.538 & 0.000 \\
\hline $\mathrm{Pair}_{2}$ & Attitude $_{2} \&$ Attitude $_{3}$ & 128 & 0.462 & 0.000 \\
\hline
\end{tabular}

From Table -2 it is observed that the coefficients correlations between the attitude scores the $1^{\text {st }} \& 2^{\text {nd }}$ phase of testing was 0.538 , between the $2^{\text {nd }} \& 3^{\text {rd }}$ phase of testing was 0.462 .

Table - 3: Paired Samples Test of Scores in Attitude

\begin{tabular}{|l|c|c|c|c|c|c|}
\hline \multicolumn{2}{|c|}{ Attitude } & \multicolumn{2}{c|}{ Paired Differences } & \multirow{2}{*}{ df } & \multirow{2}{*}{ Sig. (2-tailed) } \\
\cline { 3 - 5 } & Mean & Std. Deviation & & & \\
\hline Pair $_{1}$ & Attitude $_{1}-$ Attitude $_{2}$ & -3.60 & 8.27 & -4.925 & 127 & 0.000 \\
\hline Pair $_{2}$ & Attitude $_{2}-$ Attitude $_{3}$ & -3.23 & 10.32 & -3.546 & 127 & 0.001 \\
\hline
\end{tabular}

From the Tables -3 it is observed that mean of the attitude scores of the B.P.Ed. Students increased significantly as the course was advanced towards the completion.

\section{Discussion and Conclusion}

In the first phase, the test was administered at the beginning of the B.P.Ed. Course (in the $1^{\text {st }}$ week of July) the scores on the attitude scale actually exhibited the entry behaviour. It is observed that the attitude towards physical education of the B.P.Ed. students were positive. The students admitted to the B.P.Ed. course have inclination on physical activities. This may be the cause of the high positive attitude. After some time of running of the course in the second phase the same test was administered. Statistically significant difference (higher) was observed between the means of the attitude scores obtained in the two different phases of administration. In the final phase, the same test was administered at the completion of the course. The mean of the test scores was significantly (statistically) higher than the previous means. Here the impact of the B.P.Ed. course on development of attitude towards physical education may lie actually.

\section{Reference}

[1] Adhikari, S. (2008). Perfectionist Self-Presentation Style of Prospective General as well as Physical Education Teachers. Indian Psychological Review, Vol. 71, No. Special Issue.

[2] Adhikari, S. (2010). Impact of Physical Education Teachers Training Programme on Experience of Purpose of Life. Indian Psychological Review, Vol. 74 No. 2 Yr.

[3] Adhikari, S. (2010a). To Study the Experience of Purpose in Life of Prospective General as well as Physical Education Teachers. Asian Journal of psychology \& Education, Vol. Vol. 43 No. 3-4 Yr.

[4] Aicinena, S. (1991). The teacher and student attitudes toward physical education. The Physical Educator, Late Winter, 28-31.

[5] Browne, J. (1992). Reasons for the selection or nonselection of physical education studies by year 12 girls. Journal of Teaching in Physical Education, 11, 40410.

[6] Carlson, T. B. (1994). Why students hate, tolerate, or love gym: A study of attitude formation and associated behaviours in physical education (Doctoral dissertation, University of Massachusetts, 1994). Dissertation Abstracts International, 55-03A, 0502.

[7] Cothran, D. J., \& Ennis, C. D. (1998). Curricula of mutual worth: Comparisons of students' and teachers' curricular goals. Journal of Teaching in Physical Education, 17, 307-326.

[8] Demirhan, G., \& Altay, F. (2001). Lise birinci sinif ogrencilerinin beden egitimi ve spora ilifkin tutum olfegi II [Attitudes scale of high school first graders toward physical education and sport II]. Spor Bilimleri Dergisi, 12,9-20.

[9] Earl, L. M., \& Stennett, R. G. (1987). Student attitudes toward physical and health education in secondary schools in Ontario. Canadian Alliance of Health, Physical Education and Recreation Journal, 53 (4), 4-11.

[10] Ennis, C. D. (1996). Students' experiences in sport-based physical education: (More than) apologies are necessary. Quest, 48, 453456. 373

[11] Figley, G. E. (1985). Determinants of attitudes toward physical education. Journal of Teaching in Physical Education, 4 (4), 229 240 .

[12] Graham, G. (1995). Physical education through students' eyes and in students' voices: Introduction. Journal of Teaching in Physical Education, 14 (4), 364-371.

[13] Haladyna, T. And Thomas, G. (1979). The attitudes of elementary school children toward school and subject matters. Journal of Experimental Education, 48 (1), 18-23.

[14] Lee, A. M. (1997). Contribution of research on student thinking in physical education. Journal of Teaching in Physical Education, $16,262-277$.

[15] Luke, M.D. \& Cope, L. D. (1994). Student attitudes toward teacher behavior and program content in school physical education. The Physical Educator, Spring, 57-66.

[16] Macintosh, D. and Albinson, J. (1982). Physical education in Ontario Secondary Schools. Canadian Association for Health, Physical Education and Recreational Journal, 48 (3), 14-17.

[17] Portman, P. A. (1995). Who is having fun in physical education classes? Experiences of sixth-grade students in elementary and middle schools. Journal of Teaching in Physical Education, 14 (4), 445-453.

[18] Silverman, S. (1993). Student characteristics, practice, and achievement in physical education. Journal of Educational Research, 87, 54-61.

[19] Subramaniam, P. R., \& Silverman, S. (2000). Validation of scores from and instrument assessing student attitude toward physical education. Measurement in Physical Education and Exercise Science, 4, 29-40. 